\title{
KONSERVASI BANGUNAN KONSTRUKSI KAYU DI LINGKUNGAN KAWASAN MASJID AGUNG DEMAK
}

\author{
Oleh : \\ Drs. Eko Punto Hendro, MA \\ Dosen Fakultas Sastra Universitas Diponegoro
}

\section{Pendahuluan}

Sumber-sumber sejarah telah menunjukkan bahwa kerajaan Demak merupakan kerajaan Islam pertama di Jawa yang sangat berperan dalam proses Islamisasi di Indonesia. Bersama-sama dengan Wali Songo pada sekitar abad 1516 Masehi, kerajaan ini berhasil menanamkan pengaruh Islam di daerahdaerah antara lain Jawa, Kalimantan, Sulawesi, Maluku dan sebagai-nya, dan bersama-sama dengan Kerajaan Aceh dapat menanamkan pengaruh Islam di sebagian besar kepulauan Nusantara. Demikian besar peranan kerajaan Demak dalam membuka jalan bagi masuk dan berkembangnya Islam di Indonesia, maka hal ini merupakan sebuah jasa yang besar bagi bangsa dan negara Indonesia yang sebagian besar penduduknya memeluk agama Islam.

Masjd Agung Demak merupakan satu-satunya bangunan peninggalan Kerajaan Islam Demak Bintoro yang tersisa. Lestarinya bangunan ini karena memang merupakan life monument vang senantiaqsa digunakan dan dipelihara oleh masyarakat untuk kepentingan ibadah. Karena bangunan ini cukup tua dan sangat bersejarah, maka pemerintah kemudian juga cukup intens turut serta khususnya dalam upaya pelestarian benda cagar budaya. Bangunan utama memang sudah dapat dikonservasi dan dilestarikan dengan baik, namun secara keseluruhan dalam sistem pelestarian benda cagar budaya seperti yang diamanatkan di dalam Undang-undang Nomor 5 Tahun 1992 tentang Benda Cagar Budaya, ternyata masih kurang memadai, karena di dalam zona (mintakat) inti ternyata masih banyak dijumpai bangunan-bangunan baru milik massarakat. Namun demikian tentu saja hal ini dapat dimaklumi, karena massarakat, dalam hal ini pengurus Takmir Vasjid memang pemilik bangunan itu.

Mengingat sangat pentingnya peningealan Masjid Agung Demak terschut bagi umat Islam khususnya dan banesa Indonesia pada umumnya, maka upala pelestarian dan konservasi mestinya harus dilakukan sceara lebih komprehensif. Irtinya bahwa dengan memperhatikan nilatestetika lingkungan, maka konservasi dan pelestarian BCB tidak cukup hanya ditujukan pada bangunan utamanya saja (masjid), tetapi seharusnya juga terhadap kawasan lingkungannya. Oleh karena itu disarankan baik pemerintah pusat maupun daerah berserta masyarakat dapat menyadari sepenuhnya tentang hal ini, bahwa seyogyanya kawasan lingkungan Masjid Agung Demak juga dijadikan kawasan konservasi, dan akan sangat menganggu nilai-nilai estetika apabila lingkungan masjid berkembang tidak terkendali seperti

Selain alun-alun, ternyata di sekitar Masjid Agung Demak ditemukan beberapa bangunan lama yang dibangun pada masa pemerintah kolonial Belanda, baik oleh pemerintah maupun masyarakat. Karena itu pula sangat tepat apabila kawasan ini dijadikan sebagai kawasan konservasi, yaitu kawasan yang dilindungi dan terkendali dari pembangunan yang bersifat modernisasi. Apabila dibiarkan saja, nantinya akan sangat sulit untuk menangani kawasan ini, seperti yang telah teradi di beberapa kota, misalnya di Kota Semarang. Sebenarnya kota ini juga memiliki kawasan bersejarah, utamanya di kawasan Pasar Johar dan Kota Lama Semarang. Alun-alun kota dan bekas rumah Bupati Semarang sudah hilang sejak lama, dan walaupun belum lama ini ada upaya untuk mengembalikan alun-alun tersebut, ternyata sangat sulit dilakukan. Bahkan saat ini Pasar Johar terancam akan dibongkar, pada hal bangunan itu juga bersejarah, memiliki keunikan arsitektur dan sudah berumur lebih dari 50 tahun. Hal ini tentu saja disebabkan tidak adanya perhatian dari pemerintah maupun masyarakat untuk mengkonservasi kawasan ini, dan apabila sejak lama kawasan ini dijadikan kawasan konservasi, masa tentu akan sangat menarik sekali dan menjadi jati diri dan tetenger kota Semarang sebagai kota yang sangat unik dan bersejarah, dan selanjutnya dapat dimanfaatkan untuk kegiatan pariwisata, seni dan budara. Demikian halnva terladap perencanaan pembangunan Kota Demak, dari sisi nilai estetika lingkungan. karena di sana de Masjid Igung vang sangat berscjarah, maka pemerintah dacrah setempat harus memikirkan bahwa yang saat ini sudah mulai tampak. kawasan lingkungan masjid ini harus dijadikan kawasan konservasi, yang artinya pembangunannya terkendali dan tidak boleh ada bangunan yang bertentangan dengan nilai-nilai historis.

Menurut pengamatan penulis, hampir seluruh kota di Indonesia tidak direncanakan dengan baik, termasuk ibukota negara kita tercinta Jakarta. Hal yang paling nyata dapat dilihat tidak adanya pemisahan yang jelas kawasan-kawasan berdasarkan aspek kegiatan masyarakat kota, misalnya aspek politik, ekonomi, budaya, pemukiman, sejarah dan lain-lain. Apa yang tampak di kota-kota adalah campur aduk saling berbenturan antara aspek-aspek tersebut, dan yang benarbenar tampak hal ini telah menimbulkan kesemrawutan dan kemacetan lalu lintas. Hal ini disebabkan pusat kawasan kegiatan politis menyatu dengan pusat kegiatan ekonomis di pusat sebuah kota, bahkan ada pua pusat kegiatan agama, seni budaya dan pemukiman penduduk. Sebagai contohnya misalnya kawasan Simpang Lima Kota Semarang, di sana ada Kantor Gubernur, DPRD dan lapangan kota yang sering dimanfaatkan untuk kegiatan politis dan keagan ıaan, namun disana juga merupakan kawasan pusat perbelanjaan dan sering pula untuk digelar panggung hiburan terbuka. Dari sisi nilai estetika lingkungan, perencanaan seperti ini adalah sangat buruk, dan dampaknya tentu terjadi kesemrawutan dan kemacetan lalu lintas. Tak dapat dipungkiri bahwa aspek mentalitas masyarakat dan pejabat yang rendah, sebab hanya karena uang maka telah menghancurkan sebuah perencanaan kota yang baik. Perencanaan Kota Jogjakarta lebih baik dari pada Kota Semarang, karena pemisahan kawasan politis, ekonomis dan kawasan bersejarah lebih jelas, maka kota ini menjadi sangat unik dan banyak dikunjungi wisatawan, hanya sayangnya ada sebuah mall yang dibangun di kawasan bersejarah Malioboro, sehingga menimbulkan kesemrawutan dan kemacetan.

\section{Tinjauan Pustaka}

Menurut ahli arkeologi dari l niversitas Indonesia Prof. Dr. Mundardjito bahwa berdasarkan tujuan yang hendak dicapai, 


\section{Tematik}

studi arkeologi dapat dibagi dalam dua kelompok besar, yaitu; (1) studi untuk tujuan historiografi, dan (2) studi untuk tujuan konservasi. Istilah konservasi di sini mengacu pada pengertian yang luas meliputi perlindungan, pemeliharaan, dan pemugaran (Mundardjito, 1972).

Selanjutnya dikatakan bahwa studi kelompok (1) meliputi berbagai strategi, metode, dan teknik dalam melaksanakan pengumpulan data, pengolahan, penyimpulan, dan penjelasan hal-hal yang berkenaan dengan sistem teknologi, ekonomi, sistem kemasyarakatan, dan kepercayaan manusia masa lalu. Sedangkan studi kelompok (2) meliputi berbagai strategi, metode, dan teknik dalam melakukan pengumpulan data, pengolahan data, penyimpulan, dan penjelasan hal-hal yang berkenaan dengan sistem perlindungan (proteksi), sistem pemeliharaan (konservasi), dan sistem pemugaran (restorasi).

Selain pengertian berdasarkan pendapat Mundardjito sebagaimana telah dikemukakan di atas, ada beberapa pengertian yang dikenali oleh para praktisi, bersifat umum, dan berhubungan dengan kegiatan penanganan konservasi bangunan fisik dalam rangka upaya pelestarian bangunan peninggalan sejarah purbakala seperti berikut :

1. Pelestarian, Suatu tindakan aktif untuk membuat suatu obyek arkeologi agar obyek yang dimaksud tetap awet, aman, dan terpelihara sepanjang masa. Dengan demikian pelestarian tidak hanya bersifat fisik, tetapi juga mencakup aspek-aspek lain yang bersifat non fisik.

2. Pemeliharaan, Kegiatan membersihkan peninggalan purbakala baik yang sudah maupun yang belum dipugar agar kebersihan dan keterawatannya tetap terpelihara.

3. Preservasi (Pencegahan), Kegiatan melindungi peninggalan scjarah purbakala untuk mencegah pengaruh lingkungan yang dapat menimbulkan pelapukan bahan maupun kcrusakan struktur bangunan.

4. Konservasi (Penanggulangan), kegiatan merawat dan mengawetkan peningealan scjarah purbakala yang mengalami kerusakan atau pelapukan, agar kcawctannya dapat dijaga.

5. Pemugaran, Keglatan membongkar bangunan purbakala baik schagian maupun kescluruhan, untuk sclanjumsa disusun kembali sesuai dengan bentuk asli serta memperkuat srukturnata.

6. Rehabilitasi, Kegatan memperbaiki dan mengganti bagian bangunan kuno yang rusak, agar stabilitas bangunan dapat dijamin.

7. Konsolidasi, Kegiatan memperkuat dengan tanpa membongkar ikatan struktur atau bahan bangunan kuno agar menjadi kuat, kokoh kembali.

8. Rekonstruksi, Kegiatan menyusun kembali bangunan kuno nyang telah runtuh atau mengganti bagian yang hilang atau hancur agar bentuk bangunan dapat diwujudkan sesuai dengan aslinya.

9. Pengawasan, Kegiatan mengawasi bangunan kuno yang masih digunakan dan dipelihara oleh masyarakat (living monument), agar perubahanperubahan menyimpang dari aslinya dapat dihindari.

Penerapan tindakan konservasi di Indonesia pada awalnya terbatas pada kegiatan preservasi atau pelestarian monumen bersejarah, sebagaimana termuat di dalam Monumenten Ordonantie Statsblad No. 238. Pasal 1 dari MO. 1931, yang diantaranya menyebutkan bahwa benda atau bagian benda tak bergerak yang berusia 50 tahun ke atas dan dianggap mempunyai nilai penting bagi prasejarah, sejarah dan kesenian, termasuk juga situs yang mempunyai petunjuk kuat bahwa didalamnya terdapat benda-benda tersebut dianggap sebagai monumen, harus dilestarikan.

UU No. 5 Tahun 1992 tentang

Benda Cagar budaya yang menggantikan dan memperbarui MO. 1931. Pasal 1.1 (a) menvebutkan : benda cagar budava adalah buatan manusia, bergerak atau tidak bergerak yang berupa kesatuan atau bagian-bagiannya, atau sisanya, yang berumur sekurang-kurangnya 50 tahun atau mewakili masa gaya yang khas dan mewakili masa gava sckurang-kurangnya 50 tahun, dan dianggap mempunyai nilai penting bagi sejarah, ilmu pengetahuan dan kebudayaan. Benda cagar budaya tersebut harus dilestarikan atau dikonservasikan.

Adapun pengertian konservasi yang mencakup juga kegiatan pelestarian, menurut Burra (harter (1981), adalah :

a). Konservasi adalah segenap proses pengelolaan suatu tempat agar makna kultural rang dikandungnva terpelihara dengan baik. Konservasi dapat meliputi scluruh kegiatan pemcliharaan dan sesuai dengan situasi dan kondisi setempat, dapat pula mencakup preservasi, restorasi, rekonstruksi, adaptasi/revitalisasi dan demolisi.

b). Preservasi adalah pelestarian suatu tempat persis seperti keadaan aslinya tanpa ada perubahan, termasuk upaya mencegah penghancuran.

c). Restorasi atau rehabilitasi adalah mengembalikan suatu tempat kepada keadaan semula, dengan menghilangkan tambahan-tambahan yang ada dan memasang komponen semula tanpa menggunakan bahan baru.

d). Rekonstruksi adala h mengembalikan suatu tempat semirip mungkin dengan keadaan semula, dengan menggunakan bahan lama ataupun bahan yang baru.

e). Adaptasi atau revitalisasi adalah merubah suatu tempat agar dapat digunakan untuk fungsi yang lebih sesuai dalam hal kegunaannya, tanpa perubahan drastis atau hanya sedikir melakukan perubahan dengan dampak yang minimal.

f). Demolisi adalah menghancurkan atau merombak bangunan yang sudah rusak atau dianggap membahayakan.

Dilihat dari jenis kegiatan konservasi dan tingkat perubahan yang terjadi (Dobby, 1978), maka : demolisiakan menyebabkan perubahan total, adaptasi menyebabkan perubahan sedikit, rekonstruksi dapat menyebabkan perubahan banyak sampai total, restorasi menyebabkan perubahan sedikit atau banyak, preservasi hampir tanpa perubahan yang berarti.

Adapun prinsip yang harus diperhatikan dalam konservasi adalah:

a). Penghargaan keadaan semula dari suatu tempat, dengan sekecil mungkin melakukan intervensi fisik terhadap bangunan-bangunannya agar tidak mengubah bukti-bukti sejarah yang dimilikinya.

b). Upaya menemukan kembali makna kultural suatu tempat, dan harus dapat menjamin pemeliharaannya di masa mendatang.

c). Mempertimbangkan semua aspek yang berkaitan dengan makna kultural.

d). Upaya mempertahankan keberadaan bangunan berscjarah pada lokasinya, kecuali bila pemindahan scbagian atau scluruh bangunannya merupakan satu-satunsa cara untuk menjaga kiclestarianna.

c). Pemcliharaann latar visual yang coenk, seperti bentuk, skala, warna, tckstur dan bahan bangunan.

f). Pemahaman makna kultural dan kondisi fisik hangunan schagai dasar penentuan kebijaksanaan konscrvasi 


\section{Tematik}

yang akan diterapkan (Eko Budihardjo, 1997).

Salah satu model konservasi yang ideal telah dilakukan oleh Museum Arsitektur Meijimura, Jepang. Museum ini memiliki koleksi bangunan asli yang dibangun pada masa Meiji sebagai materi pameran tetap. Bangunan-bangunan tersebut dipindahkan dari tempat aslinya, kemudian dirakit kembali sebagai anjungan pada Museum Meijimura (Totok Roesmanto, 1997).

Kriteria penentuan obyek yang layak dikonservasikan menurut Eko Budihardjo adalah aspek estetika, kejamakan, kelangkaan, peran sejarah, keistimewaan dan perannya untuk meningkatkan kualitas dan citra lingkungan sekitar. Pertimbangan lain didasarkan pada motivasi untuk mempertahankan warisan budaya dan sejarah; motivasi terwujudnya arsitektur kota yang bervariasi, estetis; motivasi ekonomis dengan menjadikan bangunan yang dikonservasi sebagai obyek yang dapat meningkatkan nilai komersial lingkungan dan kotanya; motivasi simbolis perkembangan etnis dan budaya yang pernah hidup di lingkungan dan kotanya (Eko Budihardjo, 1986).

\section{Konservasi Bangunan Kayu di Lingkungan Kawasan Masjid Agung Demak}

Ternyata banyak bangunan berkonstruksi kayu yang dapat dijumpai di kawasan sekitar Masjid Agung Demak, ada yang memang merupakan sisa-sisa bangunan tradisional milik masyarakat yang berarsitektur Jawa pesisiran, tetapi ada pula yang termasuk di dalam kategori berarsitektur indische, yang dibangun oleh pemerintah kolonial Belanda. Seyogyanya bangunan-bangunan bersejarah yang ada di kawasan ini dilindungi dan dilestarikan, termasuk bangunan berkonstruksi kayu, guna menunjang aspek estetika lingkungan perkotaan dan perencanaan kota yang baik dan komprehensif. Beberapa bangunan konstruksi kayu yang harus dikonservasi dan dilestarikan di kawasan sekitar masjid Agung Demak ini antara lain :

\section{Kantor Dinas Kebudayaan dan Pariwisata Kabupaten Demak}

Bangunan Kantor Dinas Kebudayaan dan Pariwisata Pemerintah Kabupaten Demak yang terdapat di Jalan Sultan Fatah kawasan Kauman Demak, merupakan bangunan berarsitektur Indische yang paling unik di Demak.
Bangunan menghadap ke arah, dan sejajar dengan Jalan Daendels (sekarang menjadi Jl. Sultan Fatah), dari keunikan arsitekturnya terletak pada penyelesaian atap bagian hall yang menandai tempat tamu masuk ke dalam kantor, dan lantainya yang menggunakan konstruksi lantai panggung. Di samping itu masih terdapat keunikan konstruksi dindingnya yang terbuat dari panil-panil papan kayu berpenampang kecil yang dipasang horisontal. Panil-panil kayu demikian dalam bentuknya yang sedikit berbeda, pernah populer digunakan untuk lantai parket pada gelanggang olah-raga tertutup atau untuk lambrisering pada langit-langit rumah tinggal dan bangunan umum.

Atap bagian hall menyesuaikan denah tata ruangnya yang bertekak-tekuk maju ke depan, menghadirkan bidang atap yang unik dengan penutup atap sirap, dan diakhiri dengan semacam kuncung di bagian depan. Gunungan atap kuncung diselesaikan dengan panil-panil horisontal, yang sengaja diperlihatkan untuk mengimbangi penerapan panil-panil tegak di bagian dinding. Penambahan overhang berupa atap datar di bawah bidang atap utama, menghadirkan kesan horisontal yang lebih kuat. Upaya tersebut ma-sih ditambah lagi dengan pemberian garis horisontal pada keliling dinding, yang disele-saikan (difinish) warna kuning sebagaimana overhang di atasnya. Secara keseluruhan arsitektur Indische yang ditampilkan sangat bagus, dengan penutup atap dari sirap.

Penggunaan lantai panggung pada kantor ini menunjukkan bahwa permukaan tanah di sekitar Alun-alun pada masa kolonial Hindia Belanda sering terendam banjir. Lantai menggunakan papan setebal $3 \mathrm{~cm}$, lebar $20 \mathrm{~cm}$. Lanta tersebut ditopang oleh kombinasi balok induk dari kayu berpenampang $12 \times 18 \mathrm{~cm}$ dan balok anak dari kayu berpenampang $10 \times 12 \mathrm{~cm}$. Konstruksi balok dan lantai kayu tersebut menumpang di atas umpak pasangan bata berbentuk kubus $40 \times 40 \times$ $40 \mathrm{~cm}$. Konstruksi lantai panggung tersebut sengaja disembunvikan agar tidak

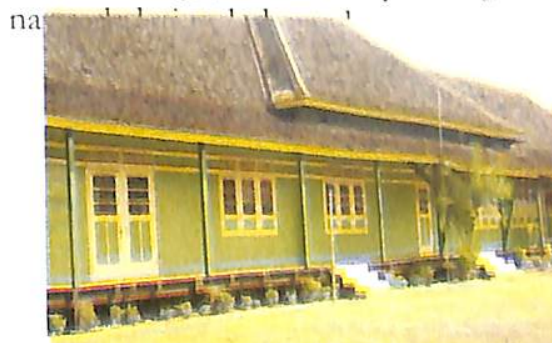

Bangunan K. antor Budp.ar
Dinding-dinding kayu pada bidang depan bangunan ini dan sebagian bidang-bidang samping, ditopang oleh konstruksi dinding bata yang permukaannya diselesaikan dengan trisik batu berukuran kecil. Batas antara dinding panil kayu dan dinding trisik dipertegas dengan plint horisontal. Kesan horisontal, agar akrab dengan lingkungan, mengingatkan pada karya Arsitektur Indische yang banyak terdapat di Malang, dan sangat erat dengan Arsitektur Organik dari arsitektur modern Frank Loyd Wright.

\section{Bangunan Kantor Pos Demak}

Bangunan Kantor Pos Demak yang terletak di sebelah selatan Alun-alun memiliki keunikan arsitektur pada bangunan kuno-nya yang terletak dekat dengan dinding keliling komplek penjara. Berbeda dengan bangunan Kantor Dinas Kebudayaan dan Priwisata (Disbudpar) Kabupaten Demak yang umpak-umpak penyangganya menempati posisi lebih teratur, umpak bangunan Kantor Pos Demak ditempatkan ritmis. Searah melebarnya bangunan, umpak dipasang dengan jarak $204 \mathrm{~cm}-186 \mathrm{~cm}-280 \mathrm{~cm}-$ $186 \mathrm{~cm}-204 \mathrm{~cm}$. Searah memanjangnya bangunan, kearah belakang, $340 \mathrm{~cm}-480$ $\mathrm{cm}-150 \mathrm{~cm}-330 \mathrm{~cm}-470 \mathrm{~cm}-210 \mathrm{~cm}$. Perbedaan jarak posisi umpak menunjukkan adanya kebebasan penempatannya yang tidak terikat lagi pada kebiasaan membuat jarak sama untuk setiap elemen utama sistem konstruksi sebagaimana biasa diterapkan pada arsitektur moderen. Pemilihan bentangbentang vang lebar, di atas 3 meter, juga menunjukkan penggunaan balok-balok kayu berpenampang besar. Kenyataannya balok penyangga konstruksi lantai panggung vang digunakan berpenampang $30 \times 30 \mathrm{~cm}$, sebanding dengan balok beton berpenampang $15 \times 30 \mathrm{~cm}$ pada bangunan berkonstruksi beton dengan jarak kolom $3 \mathrm{~m}$. umpak vang digunakan juga dari konstruksi pasangan bata, berukuran lebih besar dibandingkan umpak pada Kantor Disbudpar Kab. Demak. Dinding keliling merupakan kombinasi panil papan yang dipasang horisontal, dan deruil-deruji tegak di atasnva. Atap emper ditopang oleh konsel hesi sebagaimana biasa digunakan pada bangunan-bangunan berarsitektur Indische vang ada di kampung-kampung kota.

Savangnva bangunan kume Kantor Pos Demak ang beberapa sat vane lalu masih dalam kondisi terawat. sckarang digunakan scbagai toks swalan an walaupun tidak merusak, tetap aspek 


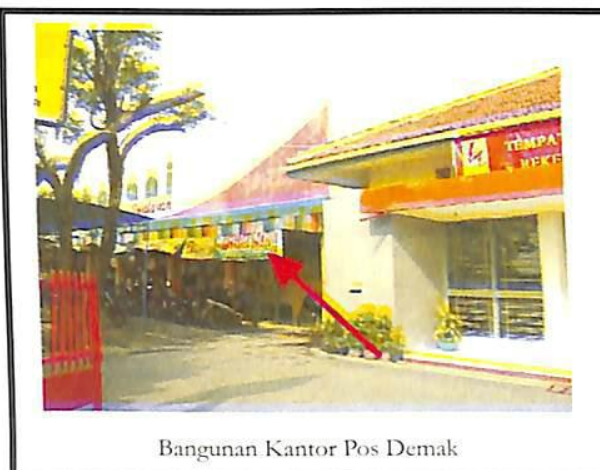

tradisional dan kekunoannya sengaja ditutup supara tidak kelihatan. Barangkali bangunan kuno bersejarah seperti ini dapat dimanfaatkan untuk apa saja sejauh tidak merusak dan tidak menghilangkan aspek estetikanya, misalnya dengan cara menutupinya. Pemanfaatan seperti itu tentu saja tidak sejalan dengan prinsip konservasi dan pelestarian seperti diamanatkan oleh Undang-undang Nomor 5 Tahun 1992 tentang Benda Cagar Budara, mengingat bangunan itu cukup unik dan usianva di atas 50 tahun dan ter tu saja akan dilindungi oleh undang-unda $\mathrm{ig}$ itu.

Bangunan gudang yang berada di belakang bangunan kuno tersebut sebenarnya juga dalam keadaan terawat, dihubungkan dengan selasar beratap pelana ke bangunan utama. Namun keberadaannya sekarang terancam rusak, sebab dipotong dan ditutupi oleh dinding batako.

\section{Bangunan Rumah Tinggal}

Bangunan rumah tinggal berusia tua masih tersisa di kampung Setinggil, tepatnya di Gang Setinggul 1 (Setinggil Jagalan) di belakang deretan Timur ruko Pecinan. Di kampung/gang Setinggil I menrisakan 3 bangunan rumah tinggal tradisional yang layak dikonservasikan. Bangunan pertama, milik keluarga Rohradi, masih memiliki soke) guru dengan tumpang sari, dada peksi masih lengkap.

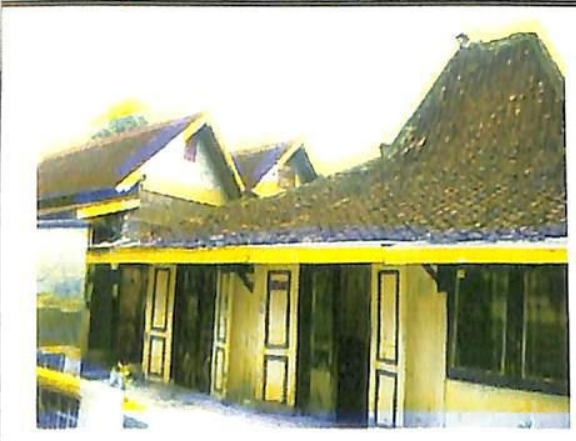

Bangunat rumah tmegal

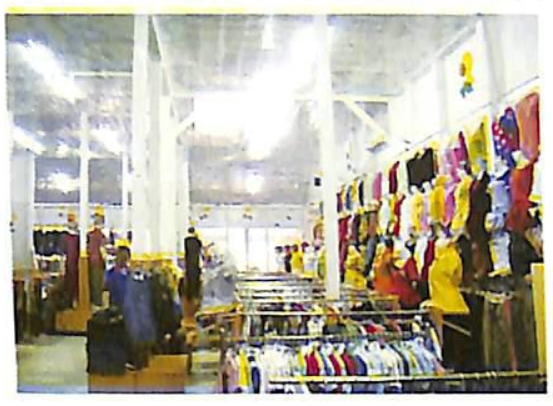

Bagian dalam Kantor Pos

permukaan dada peksi dan kapital saka gurunya menjadi tidak tampak jelas. Kapital soko-guru serupa dengan kapital soko-guru pada Masjid Menara Kudus. Tumpang sarinya dibentuk oleh blandar berpenampang $12 \times 17,5 \mathrm{~cm}$ vang menopang 5 lapis komponen tumpangsari berpenam-pang $8,5 \times 12 \mathrm{~cm}$. Keletakan komponen soko-guru membentuk balungan konstruksi penyangga atap dengan bentang $1,7 \times 3,07 \mathrm{~m}$ balungan soko-guru menopang atap bagian brunjung yang ketinggian dan bentuknya mengingatkan pada bentuk brunjung bangunan rumah tinggal tradisional Juwana. Penggunaan genteng kelir sebagaimana yang banyak digunakan pada rumah-rumah tradisional Demak, tidak menampakkan tanda-tanda ke arah penggunaannya.

Menurut penjelasan dari pengguna bangunan, mahkota yang terdapat pada ujung tepi bubungan atapnya telah mengalami kerusakan akibat ketuaan konstruksinya. Bagian mahkota yang hilang menggambarkan tentang naga, juga terdapat di bagian ujung jurai bagian brujung. Tata ruang dalam sudah mengalami perubahan, tidak lengkap karena tidak memiliki senthong tengah. Dibandingkan bangunan rumah tinggal tradisional lainnya. Bangunan ini kemungkinan berusia paling tua. Hanya saja arah hadas bangunannya ke L tara, bertentangan dengan kebiasaan arah hadap rumah tinggal tradisional Jawa (termasuk

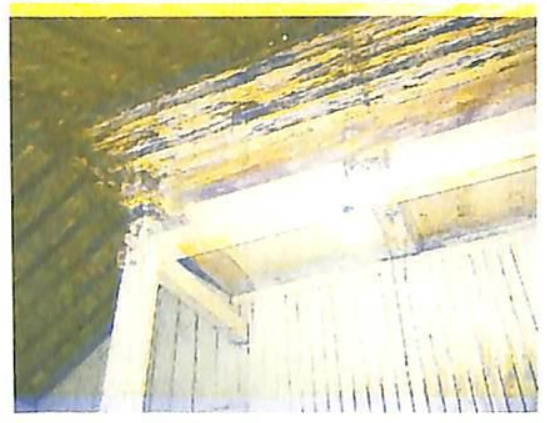

Bagtan atas bangunat

Kendismat lane kurang terawat metretratshan ormamen sane menehras di Demak) vang menghadap ke sclatan Pencrapan ragam hias berbentuk naga. vang bentuknya sulit untuk digambarkan kembali, kemungkinan merupakan salah satu bentuk akulturasi di bidang arsitektur antara Arsitektur Pecinan dan Arsitektur Tradisional/Lokal. Ragam hias berbentuk naga sendiri tidak dijumpai pada bubungan atap rumah tinggal Pecinan yang ada sekarang.

Bangunan kedua, milik keluarga Rosyidi, juga menghadap ke arah utara. Brujung atapnya 2 buah, konstruksi rangka dinding papannya menunjukkan perbedaan jarak dan penampang komponen utama, diperkirakan bangunan ini semula terdiri dari 2 buah yang kemudian digandeng menjadi satu. Penjelasan dari pengguna bangunan juga memperkuat perkiraan tersebut, karena semula bangunan tersebut dihuni oleh dua orang keluarga kakak-beradik. Ragam hias pada angin-angin di atas pintu juga menunjukkan adanya perbedaan penyelesaian detail aristekturnya.

Pintu samping Timur berbentuk kupu tarung dari kisi-kisi kayu yang dikombinasikan secara estetis. Pintu kupu tarung demikian pada rumah tinggal tradisional yang terdapat di desa-desa Demak bagian tepi, biasanya terdapat di bagian depan rumah menjadi pintu bagian luar dari pintu utama vang daun pintunya membuka ke arah dalam. Dari keadaannya saat sekarang, bagian dinding depan sudah mengalami perubahan, termasuk penghilangan atap emper depan yang telah digantikan dengan konstruksi listplank lebar. Daun pintu berukir, daun jendela berukir, usuk kayu yang dipasang dalam posisi tidur, konsol/kerbil emper samping Timur, menunjukkan sisa-sisa elemen arsitektur tradisional setempat yang masih dilestarikan.

Ragam hias pada daun jendela samping Timur memiliki komponen pengganjal (klos) yang bentuknya mengingatkan pada klos yang melengkapi daokung (konsol pada konstruksi atap emper bangunan berarsitektur (ina). Pencrapan klos tersebut diperkira-kan merupakan perwujudan dari akulturasi Irsitektur Pecinan dan arsitcktur lokal Kathek (konsol atap emper samping rumah tingeal tradisional di Demak hiasanca berbentuk sangat sederhan Inein-angin di atap pintu utama diss dengan tebeng dengan ragam hias menggunakan matahari dan 12 anak panah schagai jari-jarma.

Bangunan ketiga, milik keluarga Nusodhah menghadap $k c$ arah sclatan Masih menggunakan lantai panggung dari gladak kavu pada scluruh ruang utamanta Rathung konsol emperdepan 


\section{Tematik}

menggunakan konstruksi utama serupa dengan daokung rumah tinggal Pecinan, yang ditarik dengan sebatang besi berpenampang $1 \times 1 \mathrm{~cm}$ ke ranka kayu dinding depan. Penggunaan kabel tarik mengingatkan pada sistem konstruksi atap datar yang menaungi jendela-jendela samping bangunan berarsitektur Indische. Hal tersebut menunjukkan adanya akulturasi Arsitektur pecinan-Arsitektur Indische-Arsitektur Lokal.

Ragam hias pada daun jendela juga dapat ditemukan pada almari tua yang masih terawat dengan baik, menunjukkan adanya keselarasan antara elemen arsitektur dan elemen interior beserta perabotnya. Pintu masuk juga menggunakan konstruksi serupa dengan konstruksi jendela pada rumah tinggal Pecinan, merupakan keunikan yang tidak dijumpai pada bangunan kuno lain di Setinggil. Keunikan lain yang dimiliki adalah adanya bangunan langgar berlantai dua terletak di bagian belakang bangunan utama.

Dari bentuk atap limasan maligi gajah yang digunakan, diperkirakan bangunan ini pada awalnya dibangun dan dihuni keluarga berstrata sosial menengah (di bawah pengguna atap pencu, di atas pengguna atap kampung). Sebagai satusatunya bangunan rumah tinggal yang masih melestarikan kosntruksi panggung dengan lantai gladhak, harus dikonservasi. Penambahan bagian dapur di sebelah kanan dari bangunan utama, menggunakan atap dengan memperpanjang bidang atap emper, menunjukkan bahwa bagian yang asli adalah bangunan utamanya.

Sebuah bangunan lain yang terdapat di Setinggil I terletak di depan bangunan pencu yang konstruksi sokogurunya masih dilestarikan. Bangunan ini lebih menunjukkan penerapan Arsitektur Indische, ditampakkan dari penyelesaian konstruksi gunungan (tutup keong) dan ragam hias yang ditambahkan pada listplank dan latar depannya. Kolom emper depan dengan kathung yang mengarah ke depan dan samping, menunjukkan kesamaan dengan soko pracik pada emper ngarep rumah tinggal tradisional yang terdapat di desa-desa sekitar pusat kota Demak.

\section{Bangunan Langgar Kuno}

Di kawasan Kampung Setinggil I terdapat juga sebuah bangunan langgar berlantai dua yang berusia tua. Diperkirakan dibangun beberapa tahun setelah proklamasi kemerdekaan, bangunan yang arsitekturnya memiliki

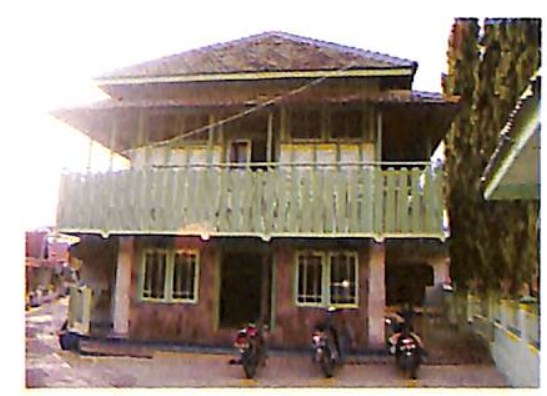

Bagian tradisional langgar

kekhasan ini, sekarang sedang mengalami peningkatan kualitas material. Keunikan yang sebetulnya dimiliki adalah bangunannya berlantai dua dari konstruksi kayu. Bentuk demikian tidak terdapat di pusat kota Demak. Bentuknya mengingatkan pada surau atau langgar yang sering menjadi pelengkap bangunan rumah tinggal tradisional Jawa, atau suku lain di luar Jawa yang biasanya ditempatkan di halaman depan.

Menurut penduduk setempat, semula lantai satu bangunan langgar tersebut adalah panggung dengan tiangtiang kayu yang menyangga lantai dua, dan untuk masuk ke langgar menggunakan tangga. Sekarang lantai satu dijadikan ruangan sholat dengan dinding tembok, dan kondisi seperti ini sebenarnya juga mengurangi keaslian dan keunikan bangunan itu.

\section{Bangunan Lain}

Beberapa bangunan rumah tinggal tradisional dapat ditemukan di kampung Kauman. Rumah tinggal tradisional ini memiliki atap bentuk kampung, beberapa masih menyisakan soko pracik dengan kathungnya di bagian emper ngarep. Peningkatan peran emper ngarep sebagai teras/serambi depan menyebabkan sebagian soko pracik bagian bawah tertutup buk dari pasangan bata. Arah hadap bangunan-bangunan rumah tinggal berarsitektur tradisional di Kauman ada yang menghadap ke arah Selatan dan Utara. Kenyataan tersebut menunjukkan perbedaan dengan ketaatan arah hadap bangunan rumah tinggal tradisional di seputar masjid Menara Kudus.

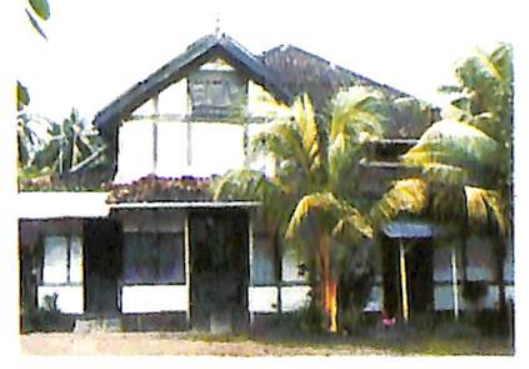

Bangunan kasu berastektur indseche
Sebuah bangunan konstruksi kayu di kawasan Kampung Kauman yang berada pada tepi Jalan Sultan Fatah (dulu Jalan Daendels) memperlihatkan penerapan Arsitektur Indische, yang ditandai dengan adanya bagian gunungan (tutup keong) pada façade depan dilengkapi dengan jendela krepyak kayu untuk lubang ventilasi yang dapat dibukatutup sesuai kehendak penggunanya.

\section{Kesimpulan}

Dari uraian di atas, maka dapat dikemukakan beberapa hal sebagai kesimpulan:

1. Karena Masjid Agung Demak merupakan Benda Cagar Budaya yang sangat penting, maka selain bangunan utama konservasi juga ditujukan terhadap lingkungannya. Tentu saja hal ini akan menambah lestarinya masjid tersebut, tetapi yang lebih penting nilai etetika lingkungan akan terjaga.

2. Untuk itu perubahan lingkungan fisik masjid harus dikendalikan, artinya bahwa lingkungan fisik masjid ini harus dibebaskan dari perubahan yang bersifat modernisasi. Di samping itu konservasi harus dilakukan terhadap bangunan-bangunan kuno yang berada di lingkungan masjid, seperti yang terdapat di kompleks Pecinan, Kompleks Kampung Kauman dan k mpleks Kampung Setinggil.

3. Eanyak bangunan kuno berkonstruksi kayu yang terdapat di kawasan lingkungan Masjid Agung Demak, dan kiranya perlu dikonservasi, antara lain bangunan kantor, rumah penduduk dan bangunan langgar, baik rang dibangun oleh Pemerintah Kolonial Belanda maupun dibangun secara tradisional oleh masyarakat pada jaman dahulu.

4. Selain kuno, bangunan-bangunan berkonstruksi kavu vang terdapat dikawasan ini sangat unik, sebab banyak yang berkonstruksi rumah panggung, ada pula yang berlantai dua, dan ada yang masih menggunakan saka guru dan blandar tumpang sari pada rumah-rumah beratap pencu. $\boldsymbol{x}$

\section{Pustaka Acuan}

Anom, I Gusti Ngurah, dkk (ed), Laporan Pemugaran Masjid Agung Demak, Jakarta-Yograkarta Provek Pemugaran dan 


\section{Tematik}

Pemeliharaan Masjid Agung Demak Tentang Penetapan Batas-batas Bantuan Presiden, 1985/1986.

Budihardjo, Eko,, Arsitektur, P e m b a n u n a d a n Konservasi, Jakarta: Djambatan, 1997.

Dobby, Alan, Conservation and Planning, London: Hutchinson, 1978.

Dradjat, Hari Untoro, 1999 , Pemintakatan Situs : kajian
Keruangan, makalah disampaikan dalam Pertemuan Ilmiah Arkeologi VIII dan Konggers IAAI Ke 8, di Yogyakarta 15-19 Februari 1999.

Totok Roesmanto, Studi Tata Ruang dan perubahan Bentuk Rumah Tinggal Tradision a 1 Sepanjang Jalan Raya DemakKudus, makalah Semarang, 1998.
Tjandrasamita, Uka (ed)., Sejarah Nasional Indonesia III, Jakarta: Balai Pustaka, 1984.

Zahad, Markus, Perancangan Kota Secara Terpadu : Teori Perancangan Kota dan Penerapannya, Yogyakarta, Semarang : Kanisius dan Soegijapranata University Press, 1999.

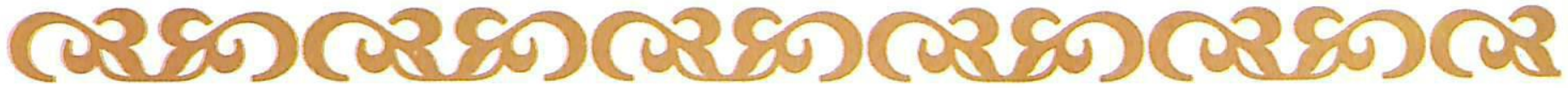

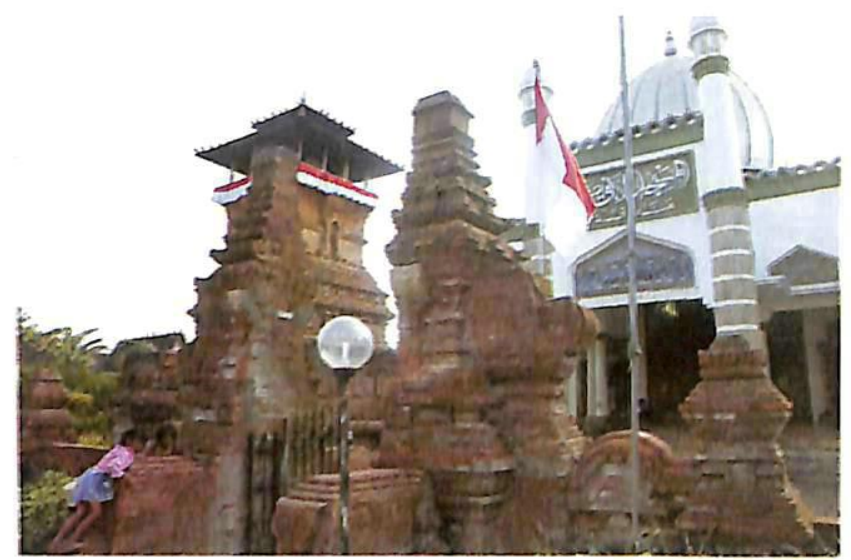

Menara Kudus

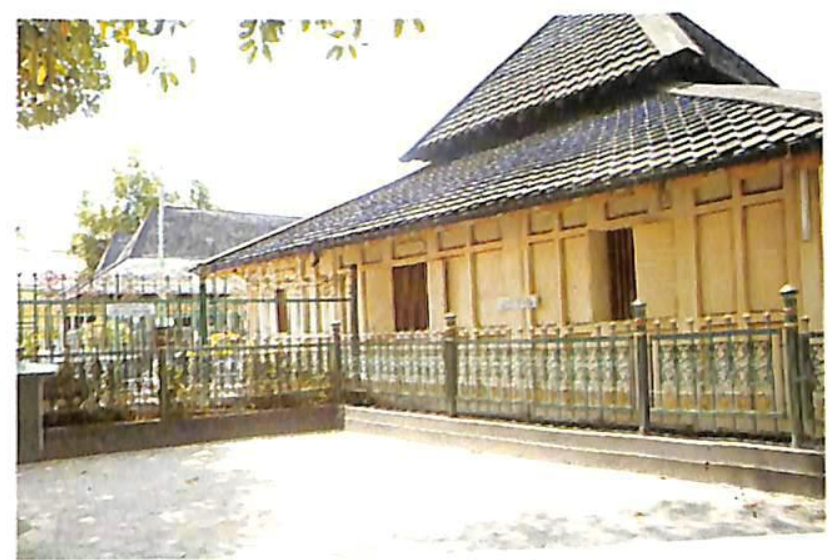

Kompleks Makam Masjid Demak

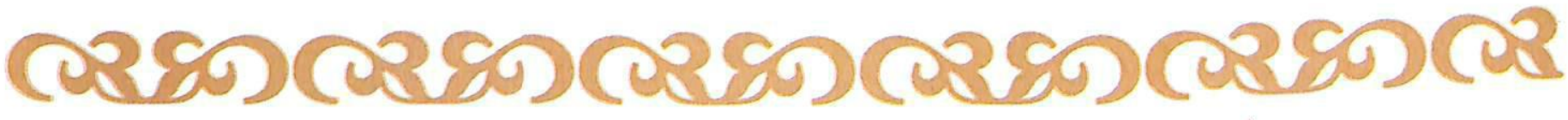

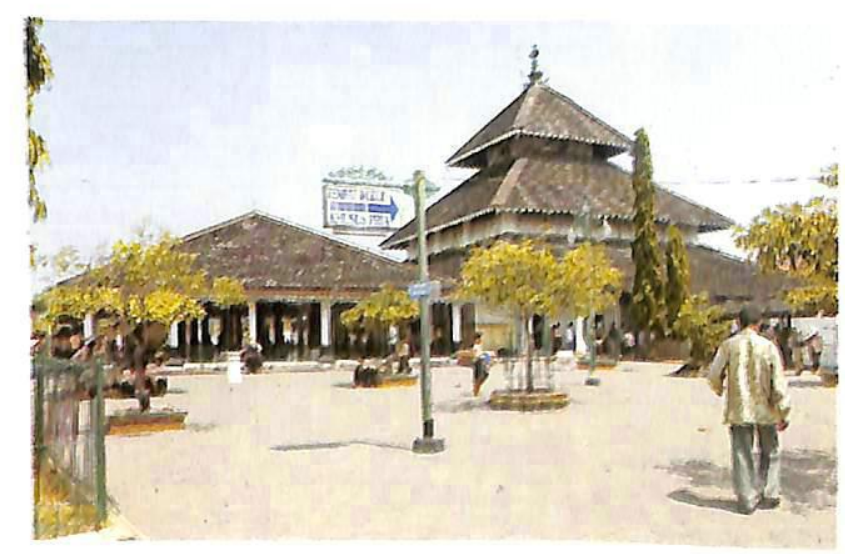

Masjid Demak

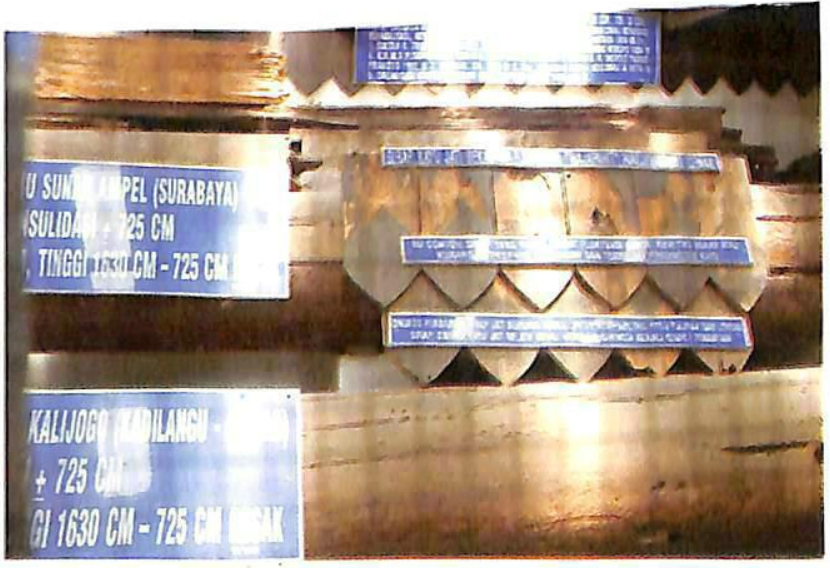

Sirap Masjid Demak 